Logistic Management

\title{
PENENTUAN RUTE KENDARAAN PADA SISTEM DISTRIBUSI LOGISTIK PASCA BENCANA (STUDI KASUS)
}

\author{
Andriansyah ${ }^{1}$, Prima Denny Sentia ${ }^{2}$ \\ ${ }^{1,2}$ Laboratorium Komputasi \& Optimasi Industri, Program Studi Teknik Industri, Universitas Syiah \\ Kuala, \\ Jalan Syekh Abdurauf As Sinkili No.7, Kopelma Darussalam, Syiah Kuala, Kota Banda Aceh, Aceh \\ 23111, Indonesia \\ E-mail: andriansyah@unsyiah.ac.id
}

\begin{abstract}
The success indicators of disaster mitigation can be seen from the disaster logistics systen. Effective and efficient distribution network can make a good disaster logistics system. The problem that related to the design of this network is the vehicle routing problem. The objective is determined optimal route of relief distribution from warehouse to victims with minimum time duration. The problem is solved by branch and bound, insertion heuristic, and local search algorithms. The results obtained by branch and bound and local search algorithm are optimal global. Time duration of vehicle using these algoritm is 1.0562 hours. However, computation time using branch and bound algorithm is very long until 22 hours while local search algorithm only takes 60 seconds. The insertion heuristic algorithm also produces a good solution. Time duration of vehicle using this algoritm is 1,1030 hours. This solution is local optimal, but the computation time is very short, only 0.001 seconds.
\end{abstract}

Keywords: Disaster, Vehicle Routing Problem, Branch and Bound, Insertion Heuristic, Local Search

Indikator keberhasilan dari penenggulangan bencana dapat dilihat dari sistem logistik bencana. Salah satu cara untuk merancang sistem logistik bencana yang baik adalah dengan membuat jaringan distribusi yang efektif dan efisien. Permasalahan yang sesuai dengan perancangan jaringan ini adalah vehicle routing problem. Fungsi tujuan dari permasalahan adalah penentuan rute optimal yntuk mendistribusikan bantuan dari gudang ke para korban dengan durasi waktu yang minimum. Metode pemecahan untuk menyelesaikan permasalahan menggunakan algoritma branch and bound, insertion heuristic, dan local search. Hasil yang didapatkan dengan algoritma branch and bound dan algoritma locai search bersifat optimal global yaitu dengan waktu tempuh 1,0562 jam. Namun waktu komputasi menggunakan algoritma branch and bound sangat lama hingga 22 jam sedangkan algoritma local search hanya membutuhkan waktu 60 detik. Algoritma insertion heuristic juga menghasilkan solusi dengan waktu tempuh 1,1030 jam. Solusi ini bersifat optimal lokal, namun waktu komputasinya sangat singkat yaitu hanya 0,001 detik.

Kata kunci: Bencana Vehicle Routing Problem, Branch and Bound, Insertion Heuristic, Local Search 


\section{PENDAHULUAN}

Setiap bencana akan menimbulkan dampak. Dampak tersebut bisa berdampak terhadap alam, maupun dampak terhadap makhluk hidup. Manusia merupakan makhluk hidup yang merasakan dampak tersebut secara langsung. Pasca terjadinya bencana, banyak yang ingin memberikan bantuan. Misalnya bencana gempa bumi dan Tsunami di Aceh pada tahun 2004 silam yang menelan korban ribuan jiwa. Berbagai bantuan sandang dan pangan datang baik dari dalam maupun dari luar negeri. Bantuanbantuan itu sukses didistribusikan ke korban, namun ada hal-hal yang harus dibenahi jika sewaktu-waktu terjadi bencana alam yang serupa, misalnya ketepatan dan kecepatan waktu pendistribusian bantuan dari gudang bencana ke para korban.

Bencana adalah permasalahan yang komprehensif dan tidak pernah habisnya. Untuk menyikapi bencana gempa bumi yang sering terjadi di Aceh, pemikiran terhadap penanggulangan bencana yang tepat dan cepat harus dipahami dan diimplementasikan oleh semua pihak terutama pemerintah. Sebagaimana telah dijelaskan dalam Undang-undang tentang penanggulangan bencana, pemerintah daerah merupakan penanggung jawab penyelenggaraan penanggulangan bencana.

Salah satu indikator yang mempengaruhi sukses atau tidaknya penanggulangan sistem bencana dapat dilihat dari sistem logistik bencana (Bintaro, 2012). Sistem logistik yang baik, akan memperlancar proses pemberian bantuan untuk paija korban. Menurut Haghani dan Afshar (2009) penyaluran barang bantuan harus dilakukan dengan cepat dan efisien sehingga memaksimalkan tingkat keselamatan penduduk. Gieh sebab itu, pemerintah perlu memperhatikan penyelenggaran sistem logistik bencana agar dapat berjalan sesuai rencana.

Sistem logistik bencana atau biasa disebut dengan Disaster Relief Operation (DRO) meliputi perencanaan, pendistribusian, dan penerimaan di tempat tujuan. Aktivitas ini mirip dengan aktifitas supply chain management (SCM) komersial sehingga secara prinsip pendekatan dan teknik SCM dapat diterapkan untuk sistem logistik bencana. Perbedaan DRO dengan SCM komersial adalah tujuan yang ingin dicapai. Pada SCM komersial, bertujuan memberikan pelayanan kepada pelanggan dengan cara yang menguntungkan, sedangkan pada DRO berfokus pada pemenuhan kebutuhan bantuan dengan cepat dan tepat. Ketersediaan pasokan yang tinggi merupakan hal yang penting dalam logistik bencana (Pujawan, Kurniati dan Wessiani, 2009). Namun, ketersediaan tersebut juga tidak bagus jika penyaluran bantuan tidak lancar.

Menurut Thomas dan Kopczak (2005) masalah utama yang sering dihadapi dalam sistem logistik bencana bukanlah jumlah pasokannya, namun pendistribusian yang lambat dan tidak tepat. Seringkali dalam pendistribusian bantuan tidak merata sehingga terjadi kesenjangan logistik antar korban bencana. Pendistribusian yang lambat bisa disebabkan karena informasi yang lambat, penerimaan dan perencanaan yang tidak tepat dan proses pendistribusian yang lankat.

Berdasarkan studi lapangan, jumlah bantuan yang yang datang ketika terjadi bencana cukup banyak, bahkan gudang penampung sudah tidak mampu menampung bantuan yang datang. Jika dilihat dari jumlah bantuan yang datang, sudah seharusnya tidak mungkin terjadi kesenjangan logistik diantara para korban. Permasalahan yang sering dihadapi adalah waktu kedatangan bantuan yang terlalu lama di penampungan para korban. Untuk mempercepat waktu kedatangan, dapat dilakukan dengan merencanakan rute kendaraan pengangkut bantuan yang efektif dan efisien. Dalam ilmu logistik permasalahan ini biasa disebut dengan vehicle routing problem (VRP).

VRP merupakan suatu permasalahan dalam dunia transportasi untuk membentuk rute-rute optimal supaya meminimumkan biaya yang berhubungan dengan transportasi (Toth \& Vigo, 2014). Dalam SCM konvensional, biaya yang dapat diminimumkan adalah biaya yang berhubungan dengan kendaraan seperti penggunaan bahan bakar dengan cara menyeimbangkan rute-rute yang memperhatikan waktu dan muatan kendaraan serta biaya pinalti akibat keterlambatan. Namun, dalam DRO biaya ini dapat diwakilkan oleh waktu tempuh kendaraan dalam satu rute. 
Penelitian lain yang berhubungan dengan penelitian ini telah dilakukan oleh Mahendra (2015) dimana dalam penelitiannya ditemukan solusi optimal dalam Travelling Salesman Problem (TSP) untuk penentuan rute distribusi bantuan bencana erupsi gunung Merapi di Yogyakarta, namun asumsi yang digunakan adalah tidak mempertimbangkan jenis logistik yang dikirimkan dan kapasitas kendaraan selalu dapat mencukupi kebutuhan yang ada. Pada kenyataannya menurut Situmorang (2014), kebutuhan logistik medis yang menjadi salah satu kebutuhan critical, dan dalam kondisi darurat selalu terdapat keterbatasan kapasitas distribusi dari kendaraan yang tersedia, hal ini juga sesuai dengan hasil penelitian dari Ozdamar dkk. (2004).

Permasalahan VRP dapat dipecahkan dengan metode analitik maupun heuristik. Pemecahan menggunakan metode analitik akan membutuhkan waktu yang lama jika jumlah titik pengungsi terlalu banyak. Hal ini disebabkan CVRP merupakan permasalahan NPhard. Permasalahan ini merupakan permasalahan yang membutuhkan waktu yang sangat lama jika dipecahkan dengan metode analitik. Semakin kompleks permasalahan, waktu yang dibutuhkan untuk memecahkan kasus tersebut akan semakin tinggi. Hubungan antara kompleksitas dan waktu dapat digambarkan secara eksponensial. Oleh karena itu untuk pemecahan permasalahan NP-hard dengan waktu komputasi singkat dan tidak mengabaikan kualitas solusi yang akan diperoleh, dalam penelitian ini akan dirancang sebuah metode metaheuristik yang cukup populer digunakan untuk menyelesaikan kasus VRP. Metode tersebut adalah algoritma local search (LS).

Suprayogi dan Priyandari (2009) menerapkan algoritma LS untuk varian VRP yang berbeda, solusi awal yang digunakan didapatkan dari algoritma penyisipan sekuensial Suprayogi dan Priyandari (2007). Dalam penelitian ini, juga akan digunakan algoritma insertion heuristic (IH) sebagai algoritma kontruksi, kemudian algoritma LS sebagai algoritma perbaikan.

\section{METODE PENELITIAN}

\subsection{Identifikasi Kebutuhan Penelitian}

Bagian ini akan menjelaskan tahapan-tahapan penelitian yang telah dilakukan. Tahap awal adalah melakukan identifikasi kebutuhan penelitian. Identifikasi masalah dilakukan dengan cara studi lapangan, wawancara dengan pihak BPBA di Banda Aceh dan studi literatur. Studi literatur dilakukan juga untuk mendapatkan model matematis dan metode pemecahan masalah yang relevan sehingga dengan metode tersebut akan didapatkan solusi terbaik yang menjawab permasalahan. Setelah permasalahan teridentifikasi, ditetapkan tujuan dan manfaat yang akan diperoleh dari hasil penelitian. Selanjutnya ditetapkan batasan masalah dan asumsi untuk menyederhanakan real system yang dihadapi.

\subsection{Implementasi Moder Matematis}

Berdasarkan studi itteratur yang telah dilakukan, maka ditetapkan satu model matematis acuan. Model matematis acuan akan dimodifikasi sesuai kebutuhan berdasarkan permasalahan, selanjutnya akan dilakukan verifikasi untuk memeriksa kebenaran dari model yang digunakan. Model matematis akan dieksekusi pada perangkat lunak optimisasi LINGO 11.0 menggunakan algoritma eksak branch-andbound (BB).

\subsection{Perancangan Algoritma}

Algoritma eksak, memiliki kekurangan yaitu waktu komputasi yang sangat lama untuk mendapatkan solusi global optimum. Oleh karena itu untuk mendapatkan solusi yang mendekati solusi global optimum dengan waktu yang cepat, akan dirancang algoritma heuristik untuk pemecahan masalah. Algoritma IH akan digunakan untuk mendapatkan solusi awal, kemudian algoritma LS digunakan untuk mecari solusi yang lebih baik atau sebagai improvement. Selanjutnya algoritma yang dirancang juga akan dilakukan verifikasi untuk memeriksa apakah solusi yang didapatkan feasible (layak) atau tidak. Algoritma akan dirancang pada bahasa pemograman MATLAB 2015a.

\subsection{Implementasi dan Analisis}

Pencarian solusi dari algoritma BB, algoritma IH dan algoritma LS, akan dijalankan pada komputer dengan spesifikasi: prosesor Intel ${ }^{\circledR}$ Core ${ }^{\mathrm{TM}}$ i5-3470 CPU@3.20GHz (4CPUs), 3.2GHz, GB RAM, dan system type 64 bit. Waktu pencarian solusi akan dibatasi selama 24 jam. Analisis dilakukan dengan 
membandingkan hasil dari algoritma $\mathrm{BB}$, algoritma IH dan algoritma LS dari data yang digunakan. telah dilakukan. Selanjutnya akan diberikan saran untuk penelitian selanjutnya supaya permasalahan yang dihadapi lebih mendekati real system.

\subsection{Penarikan Kesimpulan dan Saran}

Setelah semua tahapan penelitian dilakukan, maka akan diambil kesimpulan terhadap penelitian yang

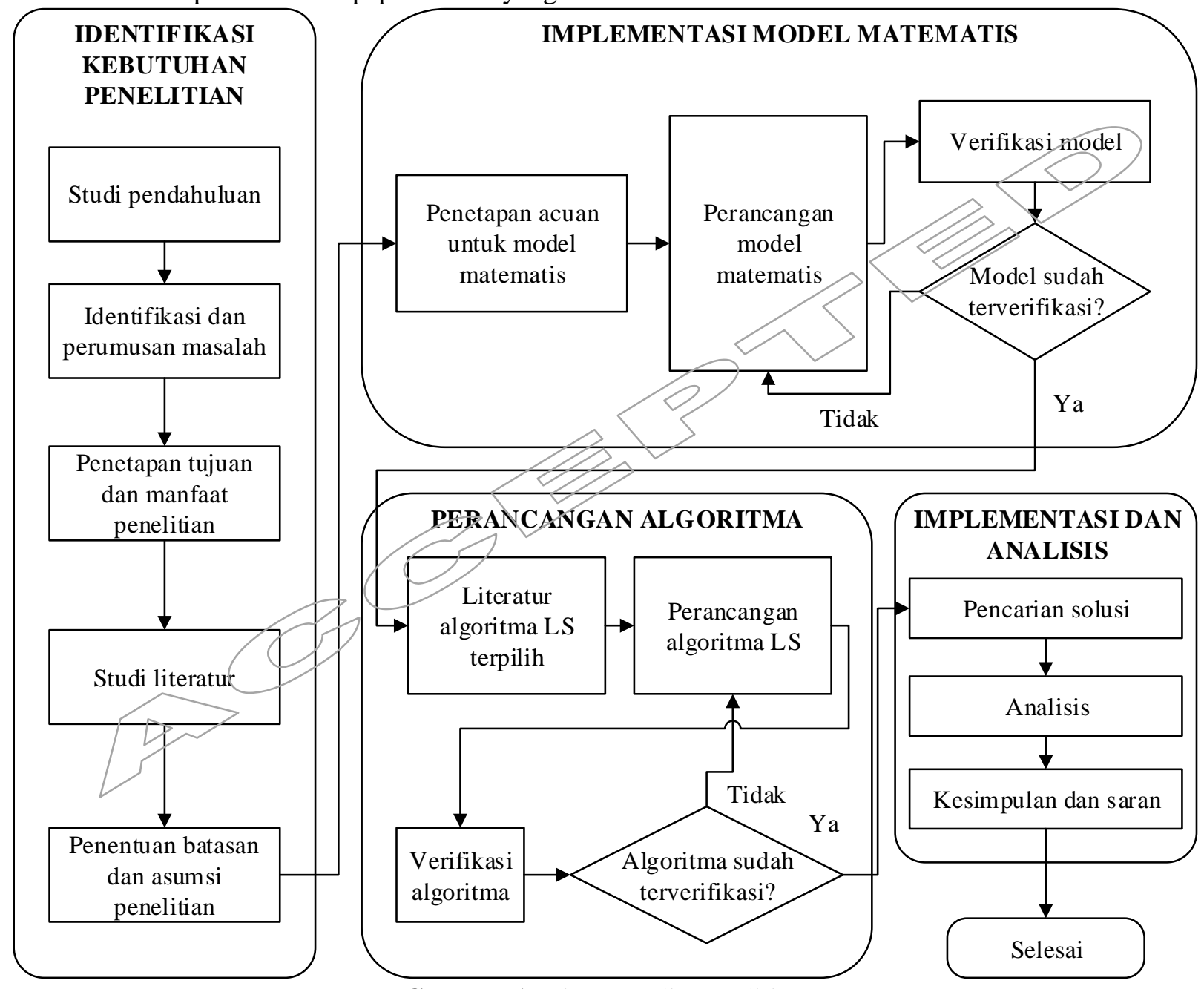

Gambar 1. Diagram alir penelitian

\section{HASIL DAN PEMBAHASAN}

\subsection{Definisi Masalah}

Terdapat sebuah jaringan $G=(V, A)$, dimana $V=$ $N \cup\{0, n+1\}$ adalah himpunan semua lokasi pemberhentian. $N$ adalah lokasi pengungsi, 0 dan $n+1$ adalah gudang logistik. Parameter $n$ merupakan jumlah lokasi pengungsi. $A$ merupakan himpunan busur $(i, j)$ antara setiap pasangan titik $i, j \in V$. Busur $(i, j) \in A$ yang terhubung menyatakan jarak antar lokasi $i$ dan $j\left(d_{i j}\right)$ dan durasi perjalanan $\left(t_{i j}\right)$. Setiap lokasi pengungsi memiliki permintaan $q_{i}$ dan setiap kendaraan yang beroperasi mengantarkan bantuan memiliki kapasitas maksimum $Q$. Fungsi tujuan adalah meminimumkan 
durasi waktu perjalanan yang dilakukan oleh setiap kendaraan.

\subsection{Model Matematis}

$$
\begin{gathered}
\min Z=\sum_{(i, j) \in A} t_{i j} x_{i j} \\
\sum_{i \in V} x_{i j}=1 ; \forall j \in N \\
\sum_{j \in V} x_{i j}=1 ; \forall i \in N \\
W_{j} \geq W_{i}+q_{j}-M\left(1-x_{i j}\right) ; \forall i, j \in V \\
W_{i} \leq Q ; \forall i \in N \\
x_{i j} \in\{0,1\} ; \forall i, j \in V
\end{gathered}
$$

Persamaan (1) merupakan fungsi tujuan yang meminimumkan durasi perjalanan. Pembatas (2) dan (3) memastikan setiap lokasi pengungsi hanya dikunjungi satu kali dalam satu horison perenanaan. Pembatas (4) memastikan konsistensi akumulasi variabel muatan $W$ dengan $M$ adalah bilangan yang sangat besar. Pembatas (5) memastikan kapasitas kendaraan $Q$ tidak terlanggai. Persamaan (6) merupakan variabel keputusan $x_{i j}, 1$ jika terjadi kunjungan, 0 jika tidak.

Dalam penelitian ini asumsi yang digunakan adalah

1. Permintaan bersifat deterministik.

2. Bantuan yang dikaji hanya bantuan beras.

3. Jenis kendaraan homogen.

4. Matriks jarak eucledian (simetris)

5. Kecepatan kendaraan tetap sebesar $60 \mathrm{~km} / \mathrm{jam}$, sehingga $t_{i j}=d_{i j}$.

\subsection{Verifikasi Model Matematis}

Verifikasi dilakukan dengan memeriksa apakah model matematis yang dirancang sudah benar satuannya dan solusi yang dihasilkan logis. Untuk memeriksa kelogisan solusi akan dilakukan pada subbab berikutnya. Berdasarkan Tabel 1, semua satuan baik ruas kanan dan ruas kiri dari persamaan/pertidaksamaan pembatas sudah sama, artinya model sudah benar berdasarkan verifikasi satuan.

Tabel 1. Verifikasi satuan

\begin{tabular}{ccc}
\hline \multirow{2}{*}{$\begin{array}{c}\text { Pembatas } \\
\text { (persamaan/pertidaksamaan) }\end{array}$} & \multicolumn{2}{c}{ Satuan } \\
\cline { 2 - 3 } & $\begin{array}{c}\text { Ruas } \\
\text { kanan }\end{array}$ & $\begin{array}{c}\text { Ruas } \\
\text { kiri }\end{array}$ \\
\hline$(2)$ & unitless & unitless \\
$(3)$ & unitless & unitless \\
$(4)$ & karung & karung \\
$(5)$ & karung & karung \\
$(6)$ & vinitless & unitless \\
\hline
\end{tabular}

\subsection{Algoritma Insertion Heuristic}

Berikut ini adalah langkah-langkah pembangkitan solusi awal menggunakan algoritma insertion heuristic.

L1. Tetapkan kendaraan $k=1$.

L2. Urutkan titik berdasarkan list kebutuhan. Buat rute sementara yang hanya terdiri dari gudang $\left(R_{k}\right)$.

L3. Pilih lokasi $i \in N$ yang paling dekat dari gudang berdasarkan kriteria algoritma.

L4. Sisipkan lokasi $i \in N$

L5. Tandai lokasi $i \in N$ sudah dikunjungi untuk menjamin setiap lokasi hanya dikunjungi satu kali.

L6. Pilih lokasi $j \in N$ sesuai urutan list permintaan kemudian sisipkan lokasi tersebut ke dalam $R_{k}$ sehingga terbentuk $R_{k}$ yang baru.

L7. Cek pembatas kapasitas dari $R_{k}$ yang terbentuk. Jika semua pembatas terpenuhi (layak) lanjut ke langkah 8, jika tidak kembali ke langkah 6. Jika tidak ada $R_{k}$ baru yang layak lanjut ke langkah 9.

L8. Pilih $R_{k}$ dengan total jarak terkecil. Tandai $j \in$ $N$ telah dikunjungi. Kembali ke langkah 6

L9. Tetapkan $k=k+1$, kembali ke langkah 2 . Jika semua lokasi telah dikunjungi, lanjut ke langkah 10.

L10. Tetapkan solusi awal $\sigma_{0}=\left\{R_{k}, \ldots, R_{k+n}\right\}$ yang terbentuk 


\subsection{Algoritma Local Search}

Berikut ini adalah langkah-langkah pembangkitan solusi awal menggunakan algoritma local search.

L1. Inisialisasi parameter jumlah generasi $(I)$ dan jumlah relokasi $(G)$.

L2. Bangkitkan solusi awal $\left(\sigma_{o}\right)$ menggunakan algoritma insertion heuristic.

L3. Tetapkan sulusi saat ini $\left(\sigma_{c}\right)=\sigma_{o}$.

L4. Lakukan perbaikan terhadap $\sigma_{c}$ sehingga menghasilkan solusi-solusi baru menggunakan operator relocation. Ilustrasi dapat dilihat pada Gambar 2 dan Gambar 3.

L5. Ambil satu solusi baru terbaik $\left(\sigma_{b}\right)$ berdasarkan fungsi tujuan.

L6. Hitung $\Delta=f\left(\sigma_{b}\right)-f\left(\sigma_{c}\right)$.

L7. Jika $\Delta<0$, tetapkan $\sigma_{c}=\sigma_{b}$, sebaliknya, tolak semua solusi baru yang tidak memberikan perbaikan.

L8. Periksa $I$. Jika sudah sama dengan nilai jumlah generasi, tetapkan $\sigma_{a}=\sigma_{c}$ kemudian berhenti, jika tidak, kembali ke langkah 4.

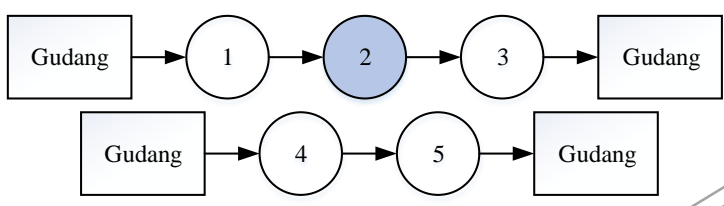

Gambar 2. Rute sebelum relocation

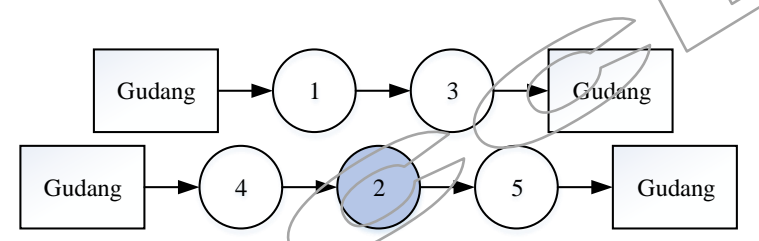

Gambar 3. Rute setelah relocation

\subsection{Hasil Percobaan}

Percobaan dilakukan pada data yang dapat dilihat pada lampiran. Data diujicobakan pada tiga algoritma, yaitu algoritma branch and bound (BB), insertion heuristic (IH) dan local search (LS). Hasil yang diperoleh dapat dilihat pada Tabel 2. Parameter algoritma LS yang digunakan adalah $I=1000 \mathrm{G}=$ 4.

Tabel 2. Solusi rute yang terbentuk

\begin{tabular}{llcc}
\hline Algoritma & Rute & $\begin{array}{c}\text { FT } \\
(\text { jam })\end{array}$ & $\begin{array}{c}\text { WK } \\
(\text { detik })\end{array}$ \\
\hline
\end{tabular}

\begin{tabular}{cccc}
\hline & $0-11-12-4-3$ & & \\
BB & $-5-6-1-7-2$ & 1,0562 & 79200 \\
& $-8-0$ & & \\
\multicolumn{5}{c}{$0-9-10-0$} \\
IH & $0-10-9-7-1-$ & & \\
& $12-4-3-5-6-$ & 1,1030 & 0.001 \\
& $2-8-0$ & & \\
\hline \multirow{4}{*}{ LS } & $0-11-12-4-3$ & & \\
& $-5-6-1-7-2$ & 1,0562 & 60 \\
& $0-8-0$ & & \\
\hline
\end{tabular}

Pada Tabel 2, FT adalah fungsi tujuan, WK adalah waktu komputasi. Dari tabel 2 dapat dilihat bahwa solusi yang didapatkan oleh algoritma LS memiliki gap $0 \%$ dengan solusi yang didapatkan oleh algoritma BB. Berbeda dengan $\mathrm{IH}$ yang memiliki gap 4,43\%. Hal ini dikarenakan algoritma LS bersifat improvement dan $\mathrm{IH}$ bersifat construction. Jika dilihat dari performansi akt komputasi, algoritma IH sangat unggui jauh dibandingkan dua algoritma yang lain. Algoritma BB memiliki waktu komputasi yang sangat lama karena algoritma ini bersifat eksak. Dari semua algoritma, LS memiliki performansi yang sangat bagus. Kualitas solusi yang ditawarkan sarigat bagus dengan waktu komputasi yang cukup singkat.

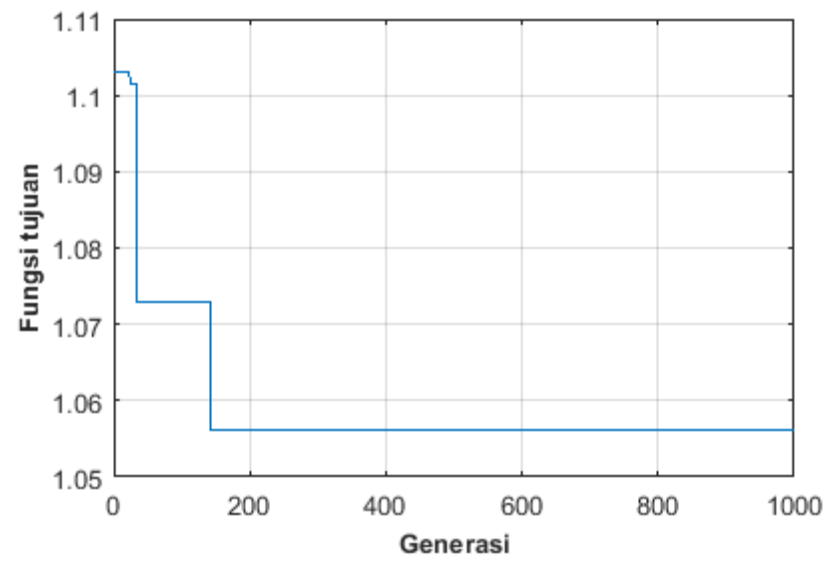

Gambar 3. Konvergensi algoritma LS

Gambar 3 menunjukkan konvergensi dari algoritma LS. Fungsi tujuan semakin kecil ketika jumlah generasi semakin meningkat dan akan berhenti ketika tidak ada solusi yang lebih baik lagi. Hal ini merupakan ciri khas dari algoritma LS. Namun, 
algoritma LS memiliki kekurangan, yaitu sangat tergantung dari jumlah generasi yang dimasukkan. Semakin banyak jumlah generasi semakin bagus, namun waktu komputasi akan semakin tinggi.

Tabel 3. Pemeriksaan solusi terhadap pembatas

\begin{tabular}{cc}
\hline Pembatas & Satus \\
\hline$(2)$ & Tidak terlanggar \\
$(3)$ & Tidak terlanggar \\
$(4)$ & Tidak terlanggar \\
$(5)$ & Tidak terlanggar \\
$(6)$ & Tidak terlanggar \\
\hline
\end{tabular}

Setelah hasil solusi telah didapatkan, maka dilakukan pemeriksaan solusi terhadap batasan. Berdasarkan tabel 3, setelah pemeriksaan tidak ada batasan yang terlanggar baik menggunakan algoritma BB, IH maupun LS, sehingga solusi sudah layak digunakan.

\section{KESIMPULAN}

Sistem logistik bencana sangat penting untuk diteliti karena berhubungan dengan hajat hidup korban bencana. Salah satu cara untuk mengoptimalkan sistem logistik bencana adalah dengan membentuk rute-rute optimal pendistribusian bantuan untuk korban bencana. Pembentukan rute optimal dilakukan dengan fungsi tujuan meminimumkan waktu tempuh kendaraan pengangkut bantuan. Berdasarkan studi kasus pendistribusian bantuan pasea bencana di Banda Aceh, dapat digolongkan dalam permasalahan VRP yang mempertimbangkan kapasitas. Dari hasil model matematis menggunakan algoritma BB dan LS didapatkan solusi optimal global, namun algoritma BB membutuhkan waktu yang sangat lama yaitu 22 jam. Sedangkan algoritma LS hanya membutubkan waktu 1 menit. Selain itu untuk membangkitkan solusi awal juga dirancang algoritma $\mathrm{IH}$, solusi yang ditawarkan tidak begitu bagus namun waktu komputasinya sangat singkat yaitu 0,001 detik.
Dalam penelitian ini, masih banyak menggunakan asumsi, misalnya kendaraan homogen, jenis bantuannya hanya satu jenis, karakteristik kebutuhan deterministik, jarak yang digunakan eucledian dan asumsi kecepatan tetap. Untuk penelitian selanjutnya dapat melanggar asumsi-asumsi tersebut, mengingat sistem logistik bencana itu sangat kompleks dan bersifat stokastik. Penelitian selanjutnya juga dapat merancang algoritma pemecahan yang lain kemudian dibandingkan dengan algoritma LS untuk kasus yang lebih besar.

\section{UCAPAN TERIMA KASIH}

Peneliti sangat berterima kasih kepada Badan Penanggulangan Bencana Aceh (BPPA) yang telah memberikan data dan informasi untuk kelancaran penelitian ini.

\section{DAFTAR PUSTAKA}

[1] Bintarg, A.G. (2012). Pengembangan logistik bencana: Pembelajaran dari Penanganan bencana erupsi merapi, Prosiding Seminar Nasional Teknologi Industri, Fakultas Teknologi Industri Universitas Trisakti, Jakarta.

[2] Haghani, Ali dan Afshar, Abbas M. (2009). Supply chain management in disaster response, Final Project Report, Departement of Civil \& Environmental Engineering University of Maryland.

[3] Pujawan, I. N., Kurniati, N., dan Wessiani, N. A. (2009). Supply Chain Management for Disaster Relief Operation: Principles and Case Studies. International Journal of Logistics System and Management, 5(6), 679-692.

[4] Thomas, A. S. dan Kopczak, L. R. (2005). From Logistic to Supply Chain Management: The Path Forward in The 
Humanitarian Sector. Fritlz Institute, 15, $1-15$.

[5] Toth, P., \& Vigo, D. (2014). Vehicle Routing Problem, Methods, and Application (2nd ed.), Philadelphia: Society for Industrial and Applied Mathematics Philadelphia (SIAM).

[6] Mahendra, M. Y. (2015). Optimasi rute distribusi bantuan logistik korban bencana merapi se-daerah Istimewa Yogyakarta. Skripsi, Departemen Teknik Mesin dan Industri: UGM.

[7] Situmorang, F. A. (2014). Identifikasi daftar kebutuhan pada korban bencana alam gunung meletus dan gempa bumi. Skripsi, Departemen Teknik Mesin dan Industri: UGM

[8] Ozdamar, L., Ekinci, E., dan Kucukyazici, B., (2004). Emergency logistic planning in natural disasters, Annals of Operations Research, 129, 217-245.

[9] Suprayogi dan Priyandari, Y. (2009). Vehicle routing problem with multiple trips, time windows, and simultaneous delivery and pickup services, Proceedings of Asia Pacific Conference on Industrial Engineering and Management, Kitakyushu, Japan, 15431552.

[10] Suprayogi, Priyandari, Y. (2007). Teknik penyisipan sekuensial untuk penentuan rute kendaraan, dengan karakteristik banyak trip, jendela waktu dan pengantaran-pengambilan simultan, Jurnal Teknik dan Manajemen Industri, 27 (3), 103-124 


\section{LAMPIRAN}

Tabel 4. Data jarak (km)

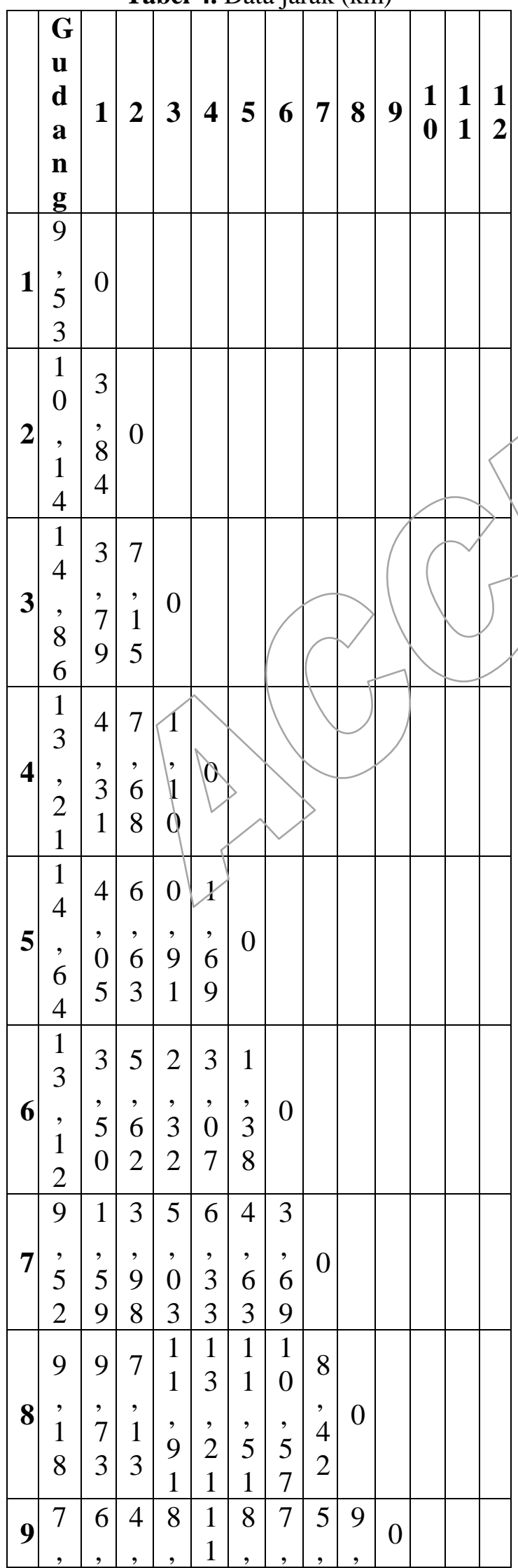

\begin{tabular}{|c|c|c|c|c|c|c|c|c|c|c|c|c|}
\hline & $\begin{array}{l}6 \\
0\end{array}$ & $\begin{array}{l}2 \\
8\end{array}$ & $\begin{array}{l}5 \\
5\end{array}$ & $\begin{array}{l}9 \\
6\end{array}$ & $\begin{array}{l}, \\
4 \\
9\end{array}$ & $\begin{array}{l}5 \\
6\end{array}$ & $\begin{array}{l}6 \\
2\end{array}$ & $\begin{array}{l}0 \\
2\end{array}$ & $\begin{array}{l}4 \\
4\end{array}$ & & & \\
\hline $\begin{array}{l}\mathbf{1} \\
\mathbf{0}\end{array}$ & $\begin{array}{l}6 \\
9 \\
9 \\
6\end{array}$ & $\begin{array}{l}, \\
0 \\
0\end{array}$ & $\begin{array}{l}4 \\
, \\
1 \\
0\end{array}$ & $\begin{array}{l}, \\
5 \\
7\end{array}$ & $\begin{array}{l}9 \\
9 \\
8 \\
4\end{array}$ & $\begin{array}{l}8 \\
, \\
1 \\
1\end{array}$ & $\begin{array}{l}7 \\
9 \\
1 \\
7\end{array}$ & $\begin{array}{c}4 \\
5 \\
5 \\
7\end{array}$ & $\begin{array}{l}8 \\
9 \\
9 \\
9\end{array}$ & $\begin{array}{l}1 \\
6 \\
3\end{array}$ & 0 & \\
\hline $\begin{array}{l}1 \\
1\end{array}$ & $\begin{array}{l}8 \\
8 \\
7\end{array}$ & $\begin{array}{l}9 \\
9 \\
5\end{array}$ & $\begin{array}{l}6 \\
4 \\
8 \\
8\end{array}$ & $\begin{array}{l}0 \\
2\end{array}$ & $\begin{array}{l}7 \\
5 \\
5\end{array}$ & $\begin{array}{l}7 \\
6 \\
0 \\
0\end{array}$ & $\begin{array}{l}4 \\
9\end{array}$ & 6 & $\begin{array}{l}3 \\
3 \\
8\end{array}$ & $\begin{array}{l}5 \\
, \\
0 \\
0\end{array}$ & $\begin{array}{l}3 \\
3 \\
4 \\
7\end{array}$ & 0 \\
\hline $\begin{array}{l}1 \\
2\end{array}$ & $\begin{array}{l}5 \\
5 \\
3\end{array}$ & 6 & $\begin{array}{l}0 \\
0 \\
7\end{array}$ & , & $\begin{array}{l}6 \\
5 \\
6\end{array}$ & $\begin{array}{l}1 \\
0\end{array}$ & $\begin{array}{l}8 \\
9 \\
1 \\
9\end{array}$ & $\begin{array}{c}6 \\
6 \\
7 \\
6\end{array}$ & $\begin{array}{l}1 \\
3 \\
2 \\
3 \\
2\end{array}$ & $\begin{array}{l}7 \\
, \\
6 \\
0\end{array}$ & $\begin{array}{c}6 \\
6 \\
0 \\
8\end{array}$ & $\begin{array}{l}4 \\
9 \\
9 \\
8\end{array}$ \\
\hline
\end{tabular}

Tabel 5. Data titik pengungsi

\begin{tabular}{|c|l|}
\hline & \multicolumn{1}{|c|}{ Lokasi Pengungsian } \\
\hline 0 & Gudang \\
\hline 1 & Lapangan Neusu \\
\hline 2 & Lapangan Bola Lambuk \\
\hline 3 & Escape Building Lambung \\
\hline 4 & Escape Building Ulee Lheu \\
\hline 5 & Escape Building Deah Glumpang \\
\hline 6 & Escape Building Alue Deah Tengoh \\
\hline 7 & Gedung Sosial \\
\hline 8 & Mesjid Jamik Darussalam \\
\hline 9 & Terminal Baru \\
\hline 10 & Mesjid Cot Masjid \\
\hline 11 & Stadion Lhong Raya \\
\hline 12 & TVRI \\
\hline
\end{tabular}


Tabel 6. Data kebutuhan beras dan jumlah pengungsi

\begin{tabular}{|c|c|c|c|}
\hline No & $\begin{array}{c}\text { Lokasi } \\
\text { Pengungsian }\end{array}$ & $\begin{array}{c}\text { Jumlah } \\
\text { Pengungsi }\end{array}$ & $\begin{array}{c}\text { Kebutuhan } \\
\text { beras/minggu } \\
\text { (karung) }\end{array}$ \\
\hline 1 & Lapangan Neusu & 409 & 77 \\
\hline 2 & $\begin{array}{l}\text { Lapangan Bola } \\
\text { Lambuk }\end{array}$ & 558 & 105 \\
\hline 3 & $\begin{array}{l}\text { Escape Building } \\
\text { Lambung }\end{array}$ & 95 & 18 \\
\hline 4 & $\begin{array}{l}\text { Escape Building } \\
\text { Ulee Lheu }\end{array}$ & 47 & 9 \\
\hline 5 & $\begin{array}{l}\text { Escape Building } \\
\text { Deah Glumpang }\end{array}$ & 41 & 8 \\
\hline 6 & $\begin{array}{l}\text { Escape Building } \\
\text { Alue Deah Tengoh }\end{array}$ & 38 & 8 \\
\hline 7 & Gedung Sosial & 59 & 12 \\
\hline 8 & $\begin{array}{l}\text { Mesjid Jamik } \\
\text { Darussalam }\end{array}$ & 413 & \\
\hline 9 & Terminal Baru & 952 & 178 \\
\hline 10 & Mesjid Cot Masjid & 293 & 55 \\
\hline 11 & $\begin{array}{l}\text { Stadion Lhong } \\
\text { Raya }\end{array}$ & & 150 \\
\hline 12 & TVRI & 295 & 56 \\
\hline
\end{tabular}

